for analysis. In most instances the data was gathered with relationships intact, resulting in clearer explanations. The data clearly defined the information transfer patterns of a specific subsocietycity managers. The success of this project relied to a large degree on the flexibility of the methodology.

Today not only must academic librarians be aware of a wide range of research methodologies to support the research being done by students and faculty, but they also are finding that research and publication have become necessary prerequisites for professional advancement. Unfortunately librarians must deal with time constraints which limit research opportunities.

One consequence of this project is that it validated a methodology that is responsive to the re- search needs of practitioners. Specifically, we found that structured observation is appropriate for use by academic librarians, when used in conjunction with interviews or other data gathering techniques, to determine the information behavior and needs of specific client groups. It is particularly effective for gathering data about client groups for which little is known.

However, for academic librarians the strength of structured observation is its adaptability to restrictive time limitations as well as its wide range of applications. It is a methodology well suited for observing classroom instruction, faculty meetings, curriculum meetings, and the individual work of specific client groups.

\title{
ACRL actions, January 1985
}

\section{Highlights of the Midwinter meetings of the ACRL Board of Directors.}

T he Board of Directors of the Association of College and Research Libraries met twice during the ALA Midwinter Meeting in Washington, D.C.: on Sunday, January 6, 1985, and Tuesday, January 8 , 1985.

\section{Activity Sections/Board relationship}

The Board voted for the second time to restructure itself to allow for greater representation by activity sections and chapter nominees (see $C \& R L$ News, September 1984, p.393, for details). The proposal will be listed on the ALA ballot this spring for ACRL membership approval.

\section{ALA/ACRL}

The Board received the report of the Task Force on ALA/ACRL and referred it to the Planning Committee to analyze and refer to appropriate ACRL units.

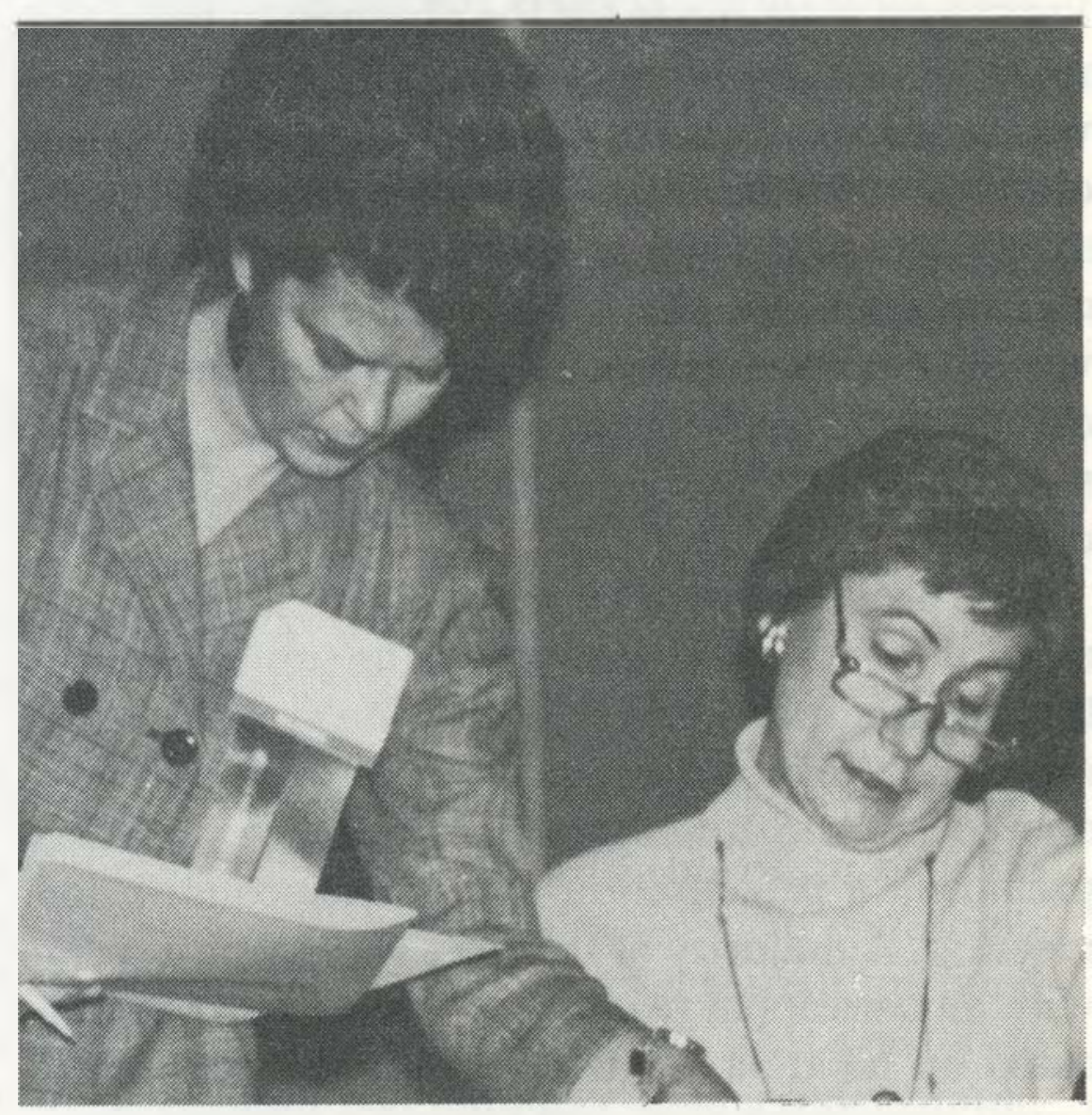

Sharon Rogers and Joan Gotwals 


\section{Swets... an attractive,}

many facetted and transparent subscription service. We would be pleased to send you our informative brochure as well as detailed documentation of our services.

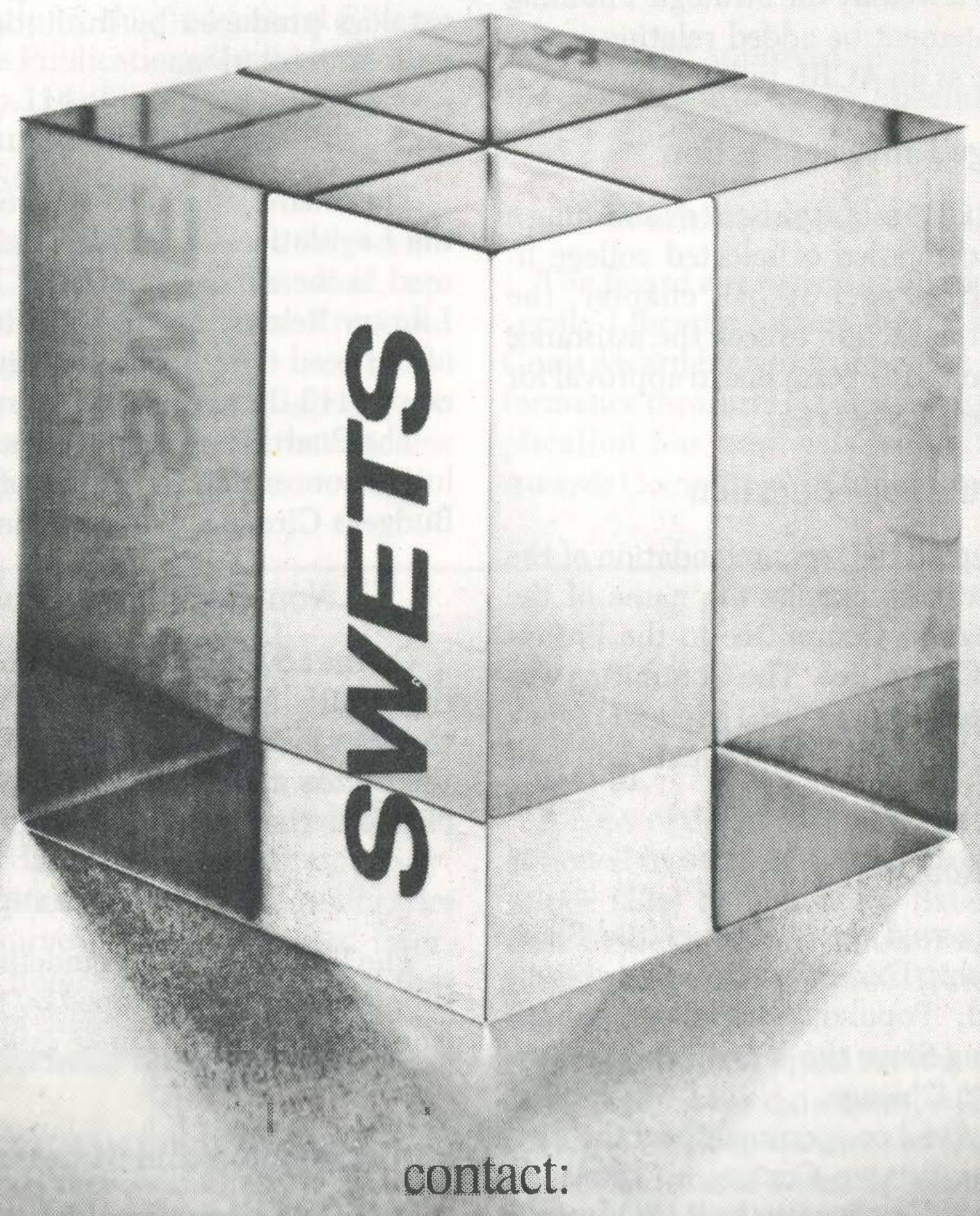

Swets Subscription Service Heereweg 347-b $2161 \mathrm{CA}$ Lisse The Netherlands 


\section{Books for College Libraries}

The Board accepted a proposal presented by Choice and UTLAS for the preparation and publication of the third edition of Books for College Libraries and that fund balances and pre-publication subscription sales be used as risk capital. The proposal has Choice acting as the manager of the project with a subcontract made with UTLAS. The Board voted to create a new committee to advise the Choice editor/publisher during the preparation and publication of the new edition.

\section{Chapters}

The Board approved petitions for the establishment of a Nevada Chapter and a Montana Chapter.

\section{Choice}

The Board reaffirmed its commitment to Choice and moved that as the ACRL mission and goals statements are reviewed by the Strategic Planning Task Force, a statement be added relating to the support of Choice as an ACRL publication.

\section{College Libraries Section}

In response to a CLS inquiry about establishing a national council composed of selected college library delegates from each ACRL chapter, the Board instructed the Section to seek the assistance of Chapters Council and obtain Board approval for any changes in the CLS bylaws.

\section{Continuing education}

The Board accepted the recommendation of the Planning Committee to change the name of the Continuing Education Committee to the Professional Education Committee. The Committee was also given a broader purpose "to study and review needs of academic librarians for graduate and continuing education."

\section{Discussion groups}

The Board approved the request of the Black Studies Librarianship Discussion Group to present a program entitled, "Popular and Scholarly Trends in Black Publishing Since the 1960s" at ALA Annual Conference in Chicago.

The Board approved co-sponsorship by the FeeBased Information Service Centers in Academic Libraries Discussion Group with the RASD Interlibrary Committee for a program at Annual Conference in Chicago on "Who Cleans Up and Who Mops Up."

The Board also approved co-sponsorship by the Public Relations in Academic Libraries Discussion Group with the LAMA Public Relations Section's Public Relations Services to Libraries Committee for a program in Chicago on "Making the Bad News Better: Crisis Management," and for
LAMA’s Swap and Shop program.

\section{Divisional Leadership Enhancement Program}

The Board supported the concept that an annual orientation for newly elected divisional officers, board members, and others be held. Division support will include financial support of approximately $\$ 100$ annually if ALA program funds are not forthcoming. The Board also supported the concept that a master training packet for committee chairs, section heads, and others be maintained by an appropriate ALA office. This packet will include documents recommended by the ALA Divisional Leadership Enhancement Program Planning Committee.

\section{Exhibition Catalog Award}

The Board approved the establishment of an RBMS Exhibition Catalog Award that will grant annual awards for the best published exhibition catalogs produced by institutions in conjunction with an exhibition.

\section{Legislation Committee}

The Board approved the recommendations of the Legislation Committee on need criteria to be used in the allocation of HEA Title II-A (College Library Resources Program) funds. A description of the need criteria and their importance appears on pp. 113-14 of this issue.

The Board also endorsed the Committee's resolution concerning the Office of Management and Budget's Circular A-76 on Federal Libraries.

\section{Non-Print Media Publications}

On the advice of the editor and editorial board of the ACRL Non-Print Media Publications series, the Board voted to discontinue the series, discharge the editor and editorial board, and transfer its charge to the Publications in Librarianship series.

\section{Publications support}

The Board approved guidelines for publications support requests developed by the ACRL Publications Committee. These guidelines appear on p.114.

\section{Rare Books and Manuscripts Journal}

The Board approved the recommendation of RBMS that ACRL develop and publish two semiannual issues of no more than 64 pages each of a journal dealing with rare books and manuscripts librarianship; that the Publications Committee monitor the status of the journal and assess its viability at the 1986 Midwinter Meeting; that the ACRL Executive Director be responsible for resolution of production issues; and that editorial responsibility reside with a temporary editor and edi- 
torial board, appointed for the two issues, in accordance with standard ACRL procedures. A market survey conducted by RBMS indicated that there is a market for such a journal.

\section{Research}

The Board accepted a Planning Committee recommendation to create an ACRL Research Committee. This new standing committee will be charged to "focus on needed current research that will support the mission of academic/research libraries; to recommend a research agenda of priorities for dissemination throughout ACRL and ALA as well as to potential funding agencies and researchers; to periodically review and update such a research agenda; and to develop ways of stimulating research in direct support of ACRL's research agenda."

\section{Section newsletters}

The Board approved a policy on section newsletters developed jointly by the Budget and Finance Committee and the Publications Committee. This policy appears on p.114 of this issue.

\section{Staff tuition}

The Board reaffirmed its policy on tuition reimbursement for ACRL Headquarters staff, approved in June 1983, and directed President Sharon Rogers to present the ACRL case to the ALA Personnel Committee. The ACRL policy sets a different limit from an ALA policy that became effective in January 1985.

\section{Standards}

The Board rescinded the 1968 Guidelines for $\mathrm{Au}$ diovisual Services in Academic Libraries. The Audiovisual Committee is in the process of developing new guidelines.

\section{Statistics}

The Board directed the Task Force on Library Statistics to complete its pilot study on statistics collection and assist the ACRL Office in developing an invitation to bid on a final project (see news item below).

\section{Strategic planning}

The Board voted to support in principle ALA's Strategic Long Range Planning Model, which was later set in motion by ALA Council. It was noted that planning for ALA will be coordinated with Division planning.

\section{WESS}

The board approved revisions to the bylaws of the Western European Specialists Section (see pp.116-18).

\section{World Book-ALA Goals Award}

The Board approved the application of the University Libraries Section for the World Book-ALA Goals Award for a preconference workshop on performance measures for academic libraries. The application has now been submitted to the ALA Awards Committee for funding consideration.

\section{Statistics help wanted}

As a result of an ongoing study to determine ACRL's role in future academic data collection, last fall the ACRL Task Force on Library Statistics collected statistical data from over 100 university, four-year college, and two-year college libraries nationwide. This survey, which requested information on 65 data items, was a pilot project that may lead to a comprehensive collection of library statistics from all academic libraries in the United States.

At the Midwinter meeting of ACRL's Board of Directors, the Task Force was charged to work with ACRL Headquarters staff to develop an invitation to contracting agencies to bid on the planned project. The current schedule calls for a questionnaire that would be sent to academic libraries in September 1985, camera-ready copy to be provided to Headquarters by early 1986, and publication in the Spring of 1986.

If your company or institution is interested in receiving an invitation to bid in April 1985, contact Sandy Whiteley, ACRL/ALA, 50 E. Huron St.,
Chicago, IL 60611-2795, (312) 944-6780, by March 31.

A copy of the pilot project questionnaire may be obtained by sending a self-addressed, stamped envelope $(22 \$)$ to George M. Bailey, Chair, ACRL Task Force on Library Statistics, Libraries of The Claremont Colleges, 800 Dartmouth Avenue, Claremont, CA 91711.

The results of the pilot survey, which contains an analysis of ten key data items, will be published this Spring. It will be sent free of charge to all survey participants, and a limited number of copies will be available for sale by the ACRL Office.

ACRL is also reviewing other options for gathering statistics: an improved U.S. Office of Education National Center for Education Statistics HEGIS process; better private sector efforts of commercial firms; and voluntary efforts by member libraries such as that done by the Association of Research Libraries and other library consortia around the nation. 